УдК 343.98

\author{
A. I. Ріпенко, А. А. Колосюк
}

\title{
ПРОБЛЕМИ МЕТОДИЧНОГО ЗАБЕЗПЕЧЕННЯ СУДОВОЇ ЕКСПЕРТИЗИ З ПИТАНЬ ЗЕМЛЕУСТРОЮ В КРИМІНАЛЬНИХ СПРАВАХ
}

Постановка проблеми. Судово-експертна діяльність регламентується сьогодні насамперед Законом України «Про судову експертизу» [1], процесуальними кодексами й низкою підзаконних нормативно-правових актів, серед яких особливе місце посідає Інструкція про призначення та проведення судових експертиз та експертних досліджень, затверджена Наказом Мін’юсту № 53/5 (далі - Інструкція) [2], а також Положенням про експертно-кваліфікаційні комісії та атестацію судових експертів, затвердженим Наказом Мін'юсту № $301 / 5$ [3].

Відповідно до ст. 1 згаданого Закону, судова експертиза - це дослідження експертом на основі спеціальних знань матеріальних об'єктів, явищ i процесів, які містять інформацію про обставини справи, що перебуває у провадженні органів досудового розслідування чи суду.

Аналіз останніх досліджень і публікацій. Питання зарахування певних знань до спеціальних дискутується в сучасній науці. Окремі автори вказують, що спеціальними є знання, що виходять за межі загальноосвітньої підготовки та життєвого досвіду [4]. Такі знання має більш-менш вузьке коло осіб. Інші дослідники підкреслюють, що до спеціальних варто зараховувати знання, що знаходяться за межами правових знань, загальновідомих узагальнень (що випливають із людського досвіду) [5].

Мета статті - вивчення проблеми недостатності методичного забезпечення судової експертизи з питань землеустрою для проведення судових експертиз по кримінальних справах.

Виклад основного матеріалу дослідження. Проведення судової експертизи в межах кримінального провадження детально регламентується Кримінальним процесуальним кодексом України (далі - КПКУ) [6]. Зокрема, відповідно до ст. 102 КПКУ, висновок судового експерта має містити докладний опис проведених досліджень, у тому числі методи, застосовані в дослідженні, отримані результати та їх експертну оцінку.

Одним із видів судових експертиз, що виконуються в кримінальних провадженнях, є інженерно-технічна експертиза, різновидом якої є експертиза з питань землеустрою. 
У результаті 26-річного реформування земельних відносин в Україні набули загрозливого поширення такі різновиди соціально-економічних протиправних явищ, як самовільне зайняття земель, порушення меж земельних ділянок, шахрайські дії стосовно заволодіння земельними ділянками та їх відчуження, перевищення повноважень з боку посадових осіб органів виконавчої влади й місцевого самоврядування під час вирішення земельних питань тощо. Отже, залучення сьогодні судових експертів до виконання судових експертиз за цим напрямом тільки набирає суттєвих обертів.

Для притягнення винних осіб до кримінальної відповідальності й постановлення об'єктивного та справедливого вироку в більшості з таких справ необхідне проведення судової експертизи.

Частина експертних завдань, що зазвичай ставляться на розгляд судових експертів, вирішується в межах експертних спеціальностей 10.7 «Земельно-технічна експертиза. Розподіл земель і визначення користування земельними ділянками», 10.14 «Оціночно-земельна експертиза. Оцінка земельних ділянок». Проте експерти, атестовані за цими експертними спеціальностями, не можуть відповісти на певні питання у сфері земельних відносин, що цікавлять слідчих, прокурорів і суддів.

Судова експертиза з питань землеустрою (індекс спеціальності 10.20) як новий вид судової експертизи з'явилась лише всередині 2015 року. Сьогодні, відповідно до Положення про експертно-кваліфікаційні комісії та атестацію судових експертів, кваліфікація за цією експертною спеціальністю (дослідження 3 питань землеустрою) присвоюється виключно фахівцям науково-дослідних установ судових експертиз Міністерства юстиції України. Тим не менше, у перспективі ця спеціальність, імовірно, буде відкрита й для судових експертів, що не працюють у державних спеціалізованих експертних установах.

Як і будь-яка інша «молода» експертна спеціальність, експертиза з питань землеустрою має певні прогалини в частині методичного забезпечення. Це $є$ однією з обставин, що зумовлюють проведення цього виду судових експертиз виключно експертами НДУСЕ Мін'юсту.

Для проведення судових експертиз розробляються, апробуються й реєструються відповідні методики, кожна з яких є результатом науково-дослідної роботи, підготовленої в установленому законом порядку. Згідно з Порядком атестації та державної реєстрації методик проведення судових експертиз, затвердженим Постановою Кабінету Міністрів України від 02.07.2008 № 595 [7], атестація методик полягає в оцінюванні звіту про наукову роботу шляхом проведення його рецензування та апробації державними спеціалізованими установами.

Рекомендовані до подальшого впровадження в експертну практику рішеннями вчених рад спеціалізованих експертних установ методики подаються для державної реєстрації та включення до реєстру, що ведеться відповідно до Порядку ведення Реєстру методик проведення судових експертиз, затвердженого Наказом Мін’юсту від 02.10.2008 № 1666/5 [8].

Натепер атестовані за експертною спеціальністю 10.20 фахівці керуються в діяльності в тому числі Методичними рекомендаціями з визначення відповідності документації із землеустрою вимогам законодавства [9]. 
Методичні рекомендації являють собою доволі місткий документ, на початку якого надається визначення основних термінів. Перший розділ рекомендацій присвячено загальним засадам проведення судових експертиз із питань землеустрою, у другому - перелічено об'єкти й суб'єкти землеустрою, третій - розглядає окремі види документації із землеустрою (проекти землеустрою та технічну документацію із землеустрою). Розділ 4 визначає загальні засади проведення судових експертиз у сфері оцінювання земель, а останній, п'ятий, розділ конкретизує об'єкти, суб'єкти, принципи й види оцінювання та документації з грошової оцінки земель (нормативної й експертної).

У науковій літературі відзначають, що методика судово-експертного дослідження є системою категоричних або альтернативних науково обгрунтованих приписів із вибору та застосування в певній послідовності та у визначених наявних або створюваних умовах методів, прийомів і засобів (пристосувань, приладів та апаратури) для вирішення експертного завдання.

Відповідно до Методичних рекомендацій «Розробка експертних методик: зміст, структура, оформлення» (КНДІСЕ, 2014. - 76 с.) [10], структура експертної методики з погляду судової експертизи має містити такі елементи:

1. Найменування (назва), реєстраційний код у Реєстрі методик.

2. Сфера застосування.

3. Перелік основних об'єктів дослідження.

4. Порівняльні об'єкти дослідження.

5. Методи, які застосовуються для вирішення експертних завдань, що вирішуються методикою.

6. Засоби вимірювальної техніки, дослідницьке (випробувальне) й допоміжне устаткування, витратні матеріали, їх мінімально необхідні характеристики.

7. Порядок проведення експертизи.

7.1. Попереднє (підготовче) дослідження.

7.2. Роздільне (аналітичне) дослідження.

7.3. Експертний експеримент.

7.4. Порівнювальне дослідження.

7.5. Оцінювання результатів (синтез) проведеного дослідження й формулювання висновків

7.6. Оформлення результатів експертного дослідження висновком.

Водночас у представленій структурі спостерігається певне змішування розуміння «методики» як сукупності способів і методів для проведення певної роботи (досягнення результату) й «методики» як документа (відповідної зовнішньої форми).

O.P. Шляховим [11] запропоновано визначення методики судової експертизи як системи методів, прийомів і технічних засобів, призначених для вивчення специфічних об'єктів експертизи й установлення фактичних даних, які стосуються предмета окремого роду, виду, підвиду судової експертизи. 
Система методів передбачає цілеспрямованість та упорядкованість їх використання. При цьому будь-яка методика експертизи - це комплекс методів, застосованих у певній послідовності (за етапами дослідження, послідовністю розв'язання підзавдань експертизи тощо). Отже, методика судової експертизи за своєю сутністю є реалізацією інтеграції методів різних галузей науки, техніки тощо для цілей судочинства.

Основна функція експертної методики спрямована на досягнення безпосередньої мети дослідження - встановлення фактів, що мають доказове значення. Це і $€$ кінцевим експертним завданням, яке може ділитися на проміжні завдання (підзавдання), від результатів яких насамкінець і залежить здійснення основної мети експертного дослідження.

Варто зазначити, що не по всіх видах судових експертиз у відповідному Реєстрі містяться необхідні методики. Так, сьогодні відсутня окрема методика за спеціальністю 10.20 «Дослідження 3 питань землеустрою», що задовольняла б указані вище критерії. Проте це не свідчить про абсолютну неможливість проведення відповідних судових експертиз.

Треба окремо зазначити, що, згідно з тематичним планом науково-дослідних робіт НДУСЕ Мін'юсту на 2017-2018 роки, фахівцями ДніпроНДІСЕ та КНДІСЕ виконується розробка методики дослідження складу, змісту і правил оформлення документації із землеустрою під час проведення судових експертиз та експертних досліджень.

Крім того, пошуковим планом Одеського НДІСЕ на 2017 рік передбачено виконання науково-дослідної роботи за темою «Методичні рекомендації 3 проведення досліджень зі встановлення відповідності вимогам законодавства технічної документації із землеустрою щодо встановлення (відновлення) меж земельної ділянки в натурі (на місцевості) для громадян». Указані розробки мають дещо заповнити вакуум у методичному забезпеченні проведення судових експертиз певних секторів питань із землеустрою.

Зрозуміло, що для «нових» видів судових експертиз методичне забезпечення їх проведення є завжди відчутною проблемою. Так, як указується в науковій літературі, під час формування нового роду (класу) судової експертизи, коли ще не розроблені методики судово-експертного дослідження, виникає ілюзія, що ніякі специфічні методики не потрібні. Нібито досить використовувати методи й методики, запозичені з материнської науки, майже без модифікацій. Але надалі підтверджується необхідність розробки специфічних судово-експертних методик і методичних рекомендацій.

Причому в літературі виділяють за ступенем загальності такі види експертних методик, як родові (видові), типові й конкретні. Зазначені види методик спрямовані на вирішення певного експертного завдання та являють собою або результат пристосування, модифікації типової експертної методики до вирішення конкретного завдання, або результат творчого підходу експерта до вирішення нетривіального експертного завдання. Проте відсутність конкретної методики не є перешкодою в наданні експертного висновку.

Так, відповідно до п. 1.4 Інструкції, під час проведення експертиз (експертних досліджень) з метою виконання певного експертного завдання 
експертами застосовуються відповідні методи дослідження, методики проведення судових експертиз, нормативно-правові акти й нормативні документи (міжнародні, національні та галузеві стандарти, технічні умови, правила, норми, положення, інструкції, рекомендації, переліки, настановні документи Держспоживстандарту України), а також чинні республіканські стандарти колишньої УРСР і державні класифікатори, галузеві стандарти й технічні умови колишнього СРСР, науково-технічна, довідкова література, програмні продукти тощо.

При цьому визначення способу проведення експертизи (вибір певних методик (методів дослідження)) належить до компетенції експерта. Отже, атестований судовий експерт самостійно обирає спосіб проведення експертизи. Зокрема, це стосується й проведення судових експертиз за спеціальністю 10.20 «Дослідження з питань землеустрою».

Інструкція в загальних рисах регламентує основні завдання експертизи з питань землеустрою (перелік цих завдань, як убачається, є невичерпним, як і перелік питань, що ставляться на вирішення судовому експерту). Основними завданнями судового експерта є такі:

1. Визначення відповідності розробленої документації із землеустрою та iï затвердження вимогам земельного законодавства та іншим нормативним документам із питань землеустрою й землекористування.

2. Визначення відповідності зміни цільового призначення земельних ділянок і ї затвердження вимогам земельного законодавства та іншим нормативним документам із питань землеустрою й землекористування.

3. Визначення відповідності фактичного землекористування правовстановлювальним документам, документації із землеустрою на земельні ділянки та нормативно-правовим актам.

4. Визначення відповідності виконаної нормативної грошової оцінки земель вимогам нормативно-правових актів.

Крім того, встановлено й орієнтовний перелік вирішуваних експертом питань, а саме:

- Чи відповідає розроблена документація із землеустрою на земельну ділянку та іï затвердження вимогам земельного законодавства та іншим нормативним документам із питань землеустрою й землекористування? Якщо не відповідають, то в чому полягають невідповідності?

- Чи змінено та затверджено цільове призначення земельної ділянки відповідно до вимог земельного законодавства та інших нормативних документів з питань землеустрою й землекористування? Якщо ні, то в чому полягають невідповідності?

- Чи відповідає фактичне землекористування правовстановлювальним документам, документації із землеустрою на земельні ділянки та нормативно-правовим актам?

- Чи відповідає виконана нормативна грошова оцінка земель вимогам нормативно-правових актів?

Як убачається з наведеного вище, питання, що ставляться судовому експерту, частково схожі на правові питання. Це певною мірою поясню- 
ється специфікою самого землеустрою як галузі на межі інженерних і правових знань. Тим не менше, важливо розуміти, що безпосередньо правові питання знаходяться поза межами експертного вирішення. А власне питання проведення «правової експертизи» та зарахування правових знань до спеціальних є дискусійним і потребує подальших досліджень.

Важливо розуміти, що для вирішення експертних завдань за спеціальністю 10.20 експерту необхідно отримати оригінали або завірені належним чином якісні копії відповідної правовстановлювальної документації та документації із землеустрою. Як свідчить майже дворічна практика, найчастіше проблема полягає саме в тому, що така документація не завжди наявна в осіб, на яких судом, прокурором чи слідчим буде покладено обов'язок надати документацію експерту, або ж у замовника експертного дослідження.

Окрім вищевказаних методичних рекомендацій, сучасне нормативно-правове забезпечення цього виду судової експертизи складається насамперед із Земельного кодексу України, Законів України «Про землеустрій», «Про оцінку земель», «Про регулювання містобудівної діяльності» й інших спеціальних законів у сферах, що регулюють питання землеустрою, а також законодавчих актів природоохоронного й іншого законодавства, нормативних та інших документів у галузі землеустрою.

Висновки. Підсумовуючи, можна стверджувати, що судова експертиза за спеціальністю 10.20 «Дослідження 3 питань землеустрою» належить до «молодих» видів судової експертизи, тому їі методичне забезпечення $є$ поки що недостатнім. Зокрема, є потреба у виробленні відповідних науково обгрунтованих методик, що відповідають названим у статті критеріям, а не лише профільних методичних рекомендацій і положень актів земельного, містобудівного та природоохоронного законодавства, стандартів і нормативних документів у галузі землеустрою, містобудування й охорони навколишнього природного середовища. Натепер системою установ судових експертиз Мін'юсту забезпечується розробка відповідних методик, що варто визнати позитивним кроком на шляху вдосконалення методичного забезпечення судової експертизи за спеціальністю 10.20 .

\section{Література}

1. Про судову експертизу : Закон України від 25.02.1994 станом на 01.01.2017 [Електронний pecypc]. - Режим доступу : http: / / zakon3.rada.gov.ua/laws/show/4038-12 - 01.01.2017.

2. Інструкція про призначення та проведення судових експертиз та експертних досліджень та Науково-методичні рекомендації з питань підготовки матеріалів та призначення судових експертиз та експертних досліджень від 08.10.2008 № 53/5 станом на 31.07.2015 [Електронний ресурс]. - Режим доступу : http: / / zakon2.rada.gov.ua/laws/show/z0705-98. - 31.07.2015.

3. Положення про експертно-кваліфікаційні комісії та атестацію судових експертів від 03.03.2015 № $301 / 5$ станом на 05.04.2016 [Електронний ресурс]. - Режим доступу : http: / / zakon2.rada.gov.ua/laws/show/z0249-15. - 05.04.2016.

4. Орлов Ю.К. Заключение эксперта и его оценка (по уголовным делам) / Ю.К. Орлов. M., 1995. - C. 6-7.

5. Треушников М.К. Судебные доказательства / М.К. Треушников. - М., 1997. - С. 269.

6. Кримінальний процесуальний кодекс України від 13.04.2012 № 4651-VI станом на 05.01.2017 [Електронний ресурс]. - Режим доступу : http: / / zakon0.rada.gov.ua/laws/ show/4651-17. - 05.01.2017. 
7. Порядок атестації та державної реєстрації методик проведення судових експертиз : Постанова Кабінету Міністрів України від 02.07.2008 № 595 станом на 15.11.2013 [Електронний pecypc]. - Режим доступу : http://zakon3.rada.gov.ua/laws/show/595-2008-\%D0\%BF. 15.11.2013

8. Порядок ведення Реєстру методик проведення судових експертиз від 02.10.2008 № 1666/5 станом на 03.07.2015 [Електронний ресурс]. - Режим доступу : http://zakon3.rada. gov.ua/laws/show/z0924-08. - 03.07.2015.

9. Методичні рекомендації з визначення відповідності документації із землеустрою вимогам законодавства : [закл. звіт]. - К. : КНДІСЕ, 2014. - 125 с.

10. Розробка експертних методик: зміст, структура, оформлення : [методичні рекомендаціï. - К. : КНДІСЕ, 2014. - 76 с.

11. Шляхов А.Р. Классификация судебных экспертиз : [учебное пособие] / А.Р. Шляхов. Волгоград : НИ и РИО ВСШ МВД СССР, 1980. - М. : ВНИИСЭ, 1982. - С. 22.

\section{А нот а ці я}

Pineнко A. I., Колосюк A. A. Проблеми методичного забезпечення судової експертизи з питань землеустрою в кримінальних справах. - Стаття.

Стаття присвячена проблемі недостатності методичного забезпечення судової експертизи з питань землеустрою для проведення судових експертиз по кримінальних справах.

Ключові слова: судова експертиза, методика проведення судових експертиз та експертних досліджень, дослідження з питань землеустрою.

\section{Анн о т а ци я}

Рипенко A. И., Колосюк A. A. Проблемы методического обеспечения судебной экспертизы по вопросам землеустройства в уголовных делах. - Статья.

Статья посвящена проблеме недостаточности методического обеспечения судебной экспертизы по вопросам землеустройства для проведения судебных экспертиз по уголовным делам.

Ключевые слова: судебная экспертиза, методика проведения судебных экспертиз и экспертных исследований, исследования по вопросам землеустройства.

\section{S u m m a r y}

Ripenko A. I., Kolosiuk A. A. Problems of the methodical providing of judicial expertise on questions of organization of the use of land in criminal cases. - Article.

The article is devoted the problem of insufficiency of the methodical providing of judicial expertise on questions of organization of the use of land for the leadthrough of judicial expertise on criminal cases

Key words: judicial expertise, method of leadthrough of judicial expertise and expert researches, research on questions of organization of the use of land. 